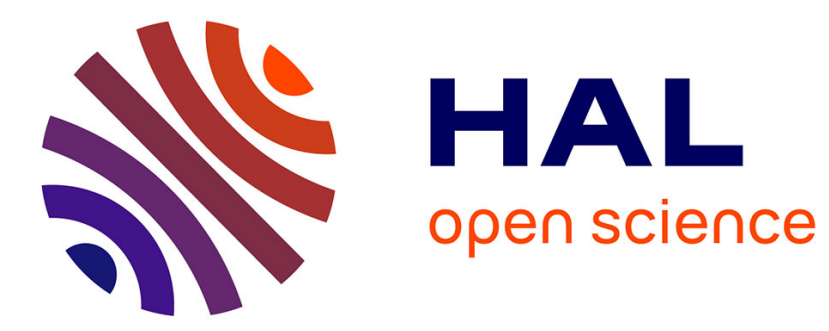

\title{
Dynamic Characterization of TiAl Intermetallic in Hot Compression
}

P. Gardiner, H. Miguélez, R. Cortés, Y. Lepetitcorps, B. Dodd, C. Navarro

\section{To cite this version:}

P. Gardiner, H. Miguélez, R. Cortés, Y. Lepetitcorps, B. Dodd, et al.. Dynamic Characterization of TiAl Intermetallic in Hot Compression. Journal de Physique IV Proceedings, 1997, 07 (C3), pp.C3593-C3-597. 10.1051/jp4:19973102 . jpa-00255386

\section{HAL Id: jpa-00255386 https://hal.science/jpa-00255386}

Submitted on 1 Jan 1997

HAL is a multi-disciplinary open access archive for the deposit and dissemination of scientific research documents, whether they are published or not. The documents may come from teaching and research institutions in France or abroad, or from public or private research centers.
L'archive ouverte pluridisciplinaire HAL, est destinée au dépôt et à la diffusion de documents scientifiques de niveau recherche, publiés ou non, émanant des établissements d'enseignement et de recherche français ou étrangers, des laboratoires publics ou privés. 


\title{
Dynamic Characterization of TiAl Intermetallic in Hot Compression
}

\author{
P. Gardiner, H. Miguélez*, R. Cortés*, Y. LePetitcorps**, B. Dodd and C. Navarro* \\ Department of Engineering, The University of Reading, Reading, U.K. \\ * Departamento de Ingeniería, Escuela Politécnica Superior, Universidad Carlos III de Madrid, \\ 28911 Leganés, Madrid, Spain \\ ** Institut de la Chimie de la Matière Condensée de Bordeaux, France
}

\begin{abstract}
In this paper the dynamic behaviour of TiAl intermetallic was studied experimentally by use of the Split Hopkinson Pressure Bar Technique. Cylindrical specimens $6 \mathrm{~mm}$ in height and $6 \mathrm{~mm}$ in diameter were dynamically compressed at temperatures ranging from $23^{\circ} \mathrm{C}$ to $800^{\circ} \mathrm{C}$. Strain rates were about $2400 \mathrm{~s}^{-1}$, except at room temperature, where strain rates ranging from $161 \mathrm{~s}^{-1}$ to $3960 \mathrm{~s}^{-1}$ were considered. The experimental results show that the TiAJ intermetallic has a relatively high yield stress and a very large strain hardening capability throughout the temperature range studied. The compression behaviour was macroscopically ductile, and specimen failure was observed only at the highest temperatures tested, and at large strain values (near 0.35 ). An SEM observation of the fracture surfaces made evident a plastic shearing mechanism along the fracture planes accompanying crack formation.
\end{abstract}

\begin{abstract}
Resumé: Le but de ce projet est l'étude du comportement dynamique de l'intermétallique gamma TiAl, en utilisant la technique de la barre de Hopkinson. Pour cela, des éprouvettes de $6 \mathrm{~mm}$ de longeur et de $6 \mathrm{~mm}$ de diamètre, ont été testées en compression dynamique, à des températures comprises entre $23^{\circ} \mathrm{C}$ et $800^{\circ} \mathrm{C}$. La vitesse de déformation de ces essais est d'environ $2400 \mathrm{~s}^{-1}$, sauf dans le cas de la température ambiente. Lors des essais à cette température, I'intervale de vitesse de déformation compris entre $161 \mathrm{~s}^{-1}$ et $3960 \mathrm{~s}^{-1}$. Ces résultats expérimentaux montrent que, à l'interieur de cet intervale d'étude, l'intermétallique présente une limite élastique relativement élevée et une très forte capacité d'écrouissage. Un examen de la surface de nupture à l'aide d'un microscope à balayage électronique, nous a permis de déterminer les caractéristiques propres à la rupture par croissance de microfissures, accompagnée déchirement plastique le long de la surface de rupture.
\end{abstract}

\section{INTRODUCTION}

The high strength and low ductility of ordered intermetallic compounds have been known since the beginning of this century. The strong tendency for chemical ordering in ordered intermetallics stems from the strong bonding between dissimilar constituent atoms, which results in a good stability of superlattice crystal structures, reduced atomic mobility at elevated temperatures, and reduced dislocation mobility and thus increased resistance to plastic deformation at elevated temperatures. In the last few years, considerable interest has been shown in titanium aluminide intermetallics because of their attractive high temperature properties such as good creep strength and oxidation resistance in addition to such useful properties as high specific strength and modulus of elasticity [1]. Hence they are being investigated for potential applications in aircraft engines and structures. The intermetallic compound $\gamma$-TiAl having a density of $3760 \mathrm{kgm}^{-3}$ and good specific properties, is an outstanding example of this kind of material. Recognising the attractive features of these materials, a group of investigators in the aerospace materials community conducted research that more than 15 years ago, led to the development of $\mathrm{Ti}-48 \mathrm{Al}+\mathrm{V}$, a twophase intermetallic alloy having $2 \%$ tensile ductility at room temperature. However, the overall properties of this alloy (particularly its creep resistance) were not competitive with the aerospace materials of that day. Research activities in the late 1980s identified several engineering alloys based on Ti-(47-49)Al, with a room temperature elongation up to $3.5 \%$ and improved strength. Remarkable improvements in fracture toughness and creep resistance and creep properties have also been achieved during the last two years, making gamma titanium aluminides potentially viable engineering alloys [2]. Ductility and strength of such materials is therefore a key factor in their design. Such properties are mainly controlled by microstructure and alloying elements. Studies on $\mathrm{Ti}-(43-55) \mathrm{Al}$ compositions showed that the lowest strength occurs at compositions around $\mathrm{Ti}-5 \mathrm{IA}$, and that room temperature elongation varies with aluminium content, exhibiting a maximum centred around the two-phase composition of Ti-48Al [3,4]. Additions of vanadium, chromium and manganese increase the ductility of two phase gamma alloys, but have no obvious effect in single phase alloys containing more than $50 \%$ aluminium. Furthermore, for a given twophase alloy composition, microstructural variations directly influence the room temperature tensile ductility, which ranges from $0.5 \%$ to $3.5 \%$ plastic elongation. Consequently, the specific role of a particular alloying element is not yet established, since both intrinsic changes in the properties of the phases and changes in the microstructure result from a given process applied to different alloys [5]. 
One of the main drawbacks in the manufacturing of components with titanium aluminides derives from its high strength and wear resistance, giving rise to rapid tool wear. For this reason, the experimental determination of the mechanical response of titanium aluminides in compression is of great practical importance. This allows us to estimate the optimum forming conditions required to minimise the energy and tool costs as a whole.

In this paper, the behaviour the $\gamma$-TiAl intermetallics in dynamic compression is studied experimentally, by use of a Split Hopkinson Pressure Bar. Testing temperatures ranged from room temperature to $800^{\circ} \mathrm{C}$. The strain rates in hot testing were about $2400 \mathrm{~s}^{-1}$, whereas at room temperature the strain rate ranged from $161 \mathrm{~s}^{-1}$ to $3960 \mathrm{~s}^{-1}$. Macroscopic specimen fracture was observed only at the highest temperatures tested. A scanning electron microscopy analysis showed that microcrack growth and plastic shearing are present along the fracture planes.

\section{EXPERIMENTAL WORK.}

Dynamic compression tests of cylindrical $\gamma$-TiAl specimens were made by use of the Split Hopkinson Pressure Bar. In this well known technique, the specimen is placed between two bars. One of them (the input bar) is impacted by a projectile, which generates an incident pulse that travels along the bar and compresses the specimen. A reflected and a transmitted wave are generated as the incident wave reaches the specimen. From the experimental recording of such waves, the stress and the strain rate in the specimen can be computed as [6]:

$$
\begin{aligned}
& s=\left(E A_{b} / 2 A_{S}\right)\left(\varepsilon_{i}+\varepsilon_{r}+\varepsilon_{t}\right) \\
& \dot{\varepsilon}=(c / l)\left(\varepsilon_{t}+\varepsilon_{\Gamma}-\varepsilon_{i}\right)
\end{aligned}
$$

where $\varepsilon$ is the strain in the bars, subindexes $i, r$ and $t$ refer to incident, reflected and transmitted pulses, respectively, $s$ is the stress in the specimen, $E$ is the Young modulus, $A b$ is the cross sectional area of the bars, $A_{\mathbf{S}}$ is the specimen cross sectional area, $\mathrm{c}$ is the propagation speed of the compression waves and $l$ is the specimen height. From Equation (2) we can compute the strain in the specimen as:

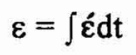

Gamma TiAl intermetallic specimens were $6 \mathrm{~mm}$ in height and $6 \mathrm{~mm}$ in diameter. Its chemical composition was near $56.11 \% \mathrm{Ti}, 38.52 \% \mathrm{Al}, 2.73 \% \mathrm{Nb}$ and $2.63 \% \mathrm{Mn}$. Electro discharge machining was used to make the specimens. Specimens tested at room temperature were cross-sectioned along a diametrical plane and examined by optical and electron microscopy.

The initial microstructure of the intermetallic alloy studied consisted of grains of gamma phase (TiAl) and grains with a lamella arrangement of phases $\gamma$ (TiAl) and $\alpha_{2}\left(\mathrm{TiAl}_{3}\right)$. Observation of the deformed microstructure under slow strain rate testing, shows that plastic straining gives rise to a structure of elongated lamellae which can be as long as $800 \mu \mathrm{m}$ and as wide as $50 \mu \mathrm{m}$. The size of the lamellae increases with increasing plastic deformation, and are oriented at 45 degrees with respect to the axis of compression. Microstructural damage, which increases with the plastic strain, localises around the lamella structure generated by the plastic strain. Firstly, cavities are nucleated at the ends of such lamellae, near the gamma phase grains. Later, cavities develop at the edges of the lamellae, between the $\gamma$ and the $\alpha_{2}$ phases, and coalesce giving rise to crack formation along the edges of the lamellae. When such cracks grow enough, they can penetrate into the gamma phase grains. Specimens tested at high strain rates show essentially the same damage mechanisms as in slow strain rate testing.

Microhardness tests were also made for the material tested at slow strain rates, using a $300 \mathrm{~g}$ load. In the undeformed microstructure the gamma phase grains and the $\gamma+\alpha_{2}$ grains have a similar hardness value. The microhardness increases with increasing plastic strain, such an increase being much more important in the $\gamma+\alpha_{2}$ grains than in the $\gamma$ grains. For instance for a microscopic strain of $\varepsilon=0.31$, the microhardness of the $\gamma$ phase increases by about $60 \%$, whereas in the $\gamma+\alpha_{2}$ grains the increase is $120 \%$. approximately.

Average strain rates in dynamic compression tests performed at room temperature ranged from $161 \mathrm{~s}^{-1}$ to $3960 \mathrm{~s}^{-1}$. Figures 1 and 2 show the true stress-true strain curves for strain rates of $945 \mathrm{~s}^{-1}$ and $3960 \mathrm{~s}^{-1}$, respectively. A large amount of strain hardening capability of the $\gamma$-TiAl intermetallic is evident from such figures. Furthermore, Figures $3,4,5$ and 6 show the true stress-true strain curves for tests performed at $400^{\circ} \mathrm{C}, 600^{\circ} \mathrm{C}, 700^{\circ} \mathrm{C}$ and $800^{\circ} \mathrm{C}$. As indicated in these latter figures, the average strain rate in hot dynamic compression tests ranged from $2320 \mathrm{~s}^{-1}$ at $600^{\circ} \mathrm{C}$ to $2500 \mathrm{~s}^{-1}$ at $700^{\circ} \mathrm{C}$. Macroscopic fracture of the specimen was only observed in the tests made at $800^{\circ} \mathrm{C}$, where the specimens shattered into several fragments. At $700^{\circ} \mathrm{C}$ gross cracking of the specimen was observed, but the specimen did not break into pieces. 


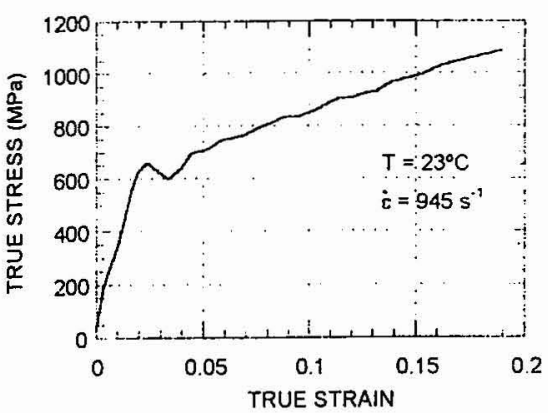

Figure 1. True stress-true strain curve for a test performed at $23^{\circ} \mathrm{C}$ and $945 \mathrm{~s}^{-1}$

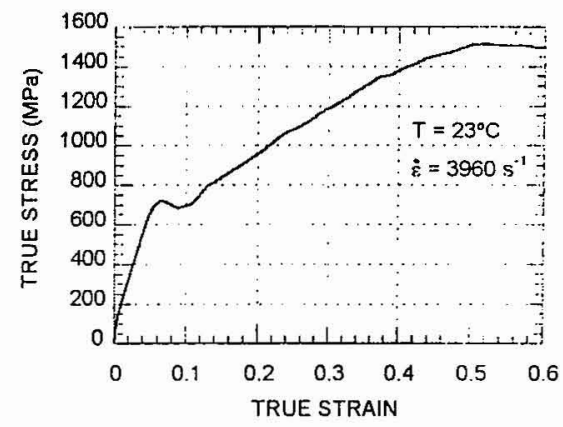

Figure 2. True stress-true strain curve for a test performed at $23^{\circ} \mathrm{C}$ and $3960 \mathrm{~s}^{-1}$

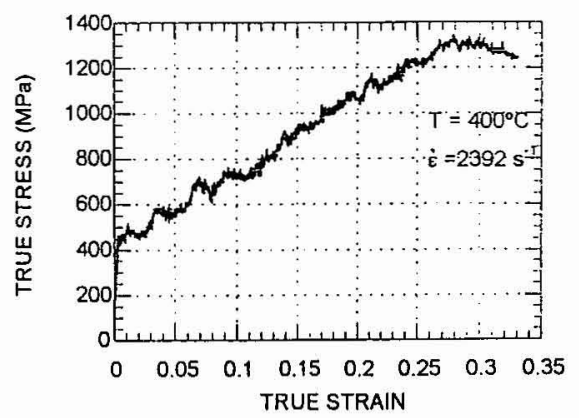

Figure 3. True stress-true strain curve for a test performed at $400^{\circ} \mathrm{C}$ and $2392 \mathrm{~s}^{-1}$

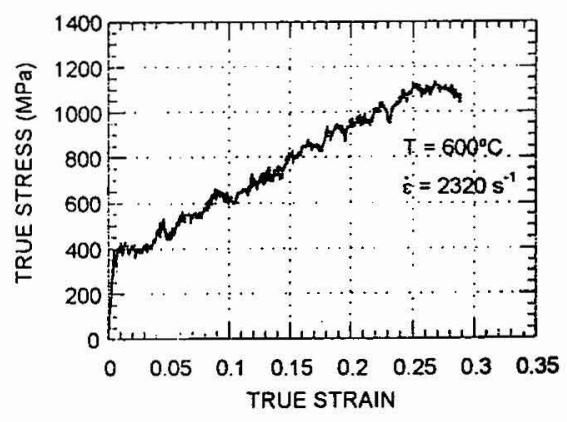

Figure 4. True stress-true strain curve for a test performed at $600^{\circ} \mathrm{C}$ and $2320 \mathrm{~s}^{-1}$

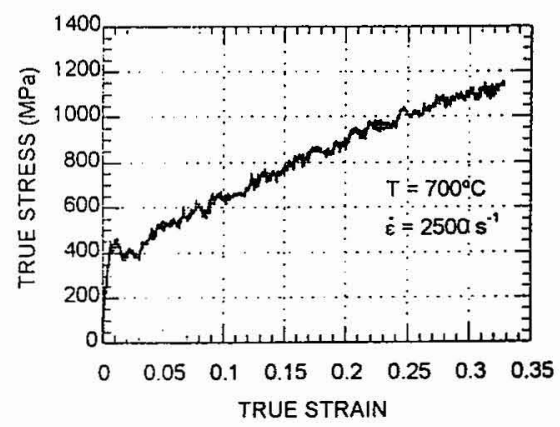

Figure 5. True stress-true strain curve for a test performed at $700^{\circ} \mathrm{C}$ and $2500 \mathrm{~s}^{-1}$

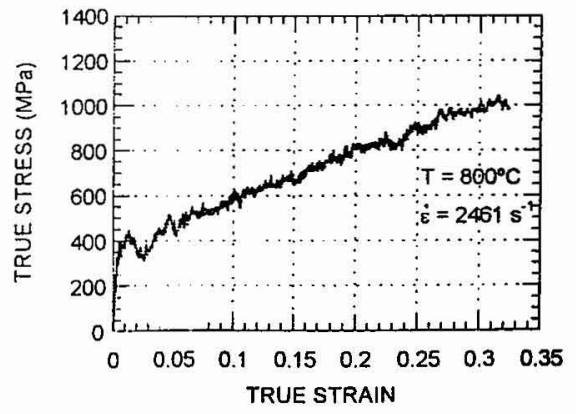

Figure 6. True stress-true strain curve for a test performed at $800^{\circ} \mathrm{C}$ and $2461 \mathrm{~s}^{-1}$ 
In all the curves shown, an important strain hardening capability of the material is evident. Furthermore, a shifting of the curves to lower stress values takes place as the testing temperature increases.

Inspection of the specimen tested at $800^{\circ} \mathrm{C}$ showed that the fracture planes develop at about 45 degrees with respect to the compression axis. An SEM observation of the fracture surfaces made evident plastic shearing along the fracture surfaces (see Figure 7) accompanying microcrack formation (see Figure 8).

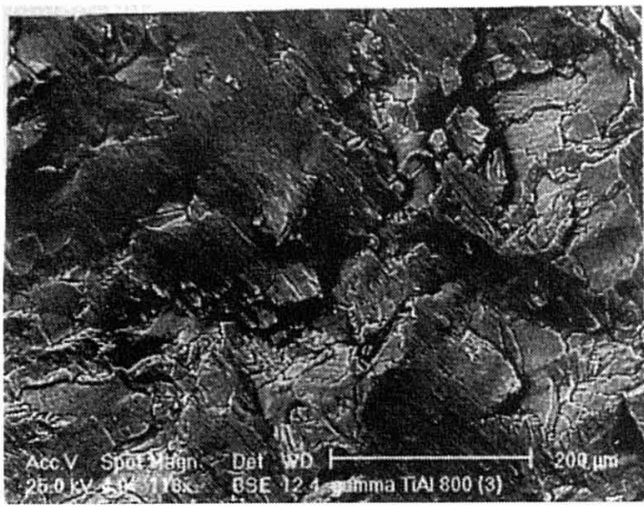

Figure 7. A view of the fracture surface

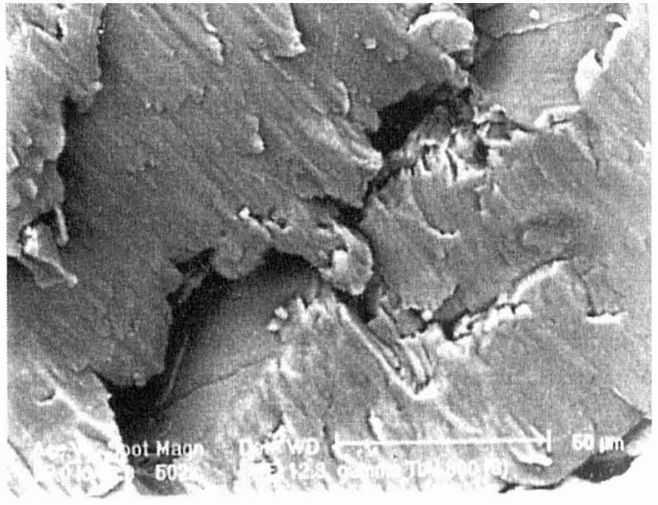

Figure 8. A view of a microcrack in the fracture surface

\section{DEVELOPMENT OF A CONSTITUTIVE EQUATION FOR TiAI}

From the tests carried out at elevated temperatures, it is observed that there is a tendency for the TiA material to strain harden at lower levels when the temperature is increased. These elevated temperature results can be modelled using the Johnson-Cook equation $[7,8]$ :

$$
\sigma=\left[A+B \varepsilon^{n}\right]\left[1+C \ln \varepsilon^{*}\right]\left[1-T^{* m}\right]
$$

Where $\hat{\varepsilon}^{*}=\hat{\varepsilon} / \hat{\varepsilon}_{0}$ is the dimensionless plastic strain rate taking $\hat{\varepsilon}_{0}=1 \mathrm{~s}^{-1}$, and $\mathrm{T}^{*}$ is the homologous temperature. The constants in the Johnson Cook equation for TiAl have been found to be as follows: $\mathrm{A}=290^{*} 10^{6}(\mathrm{MPa}), \mathrm{B}=1.77^{*} 10^{9}(\mathrm{MPa}), \mathrm{n}=0.55, \mathrm{C}=0.006$ and $\mathrm{m}=2.787(\mathrm{n}, \mathrm{C}$ and $\mathrm{m}$ are dimensionless). Using these constants, the stress-strain curves at elevated temperatures could be modelled reasonably accurately.

\section{DISCUSSION.}

The high plastic strain values reached in the dynamic compression tests, show that the gamma titanium aluminide studied can be subjected to high speed forming processes. Heating the material to $800^{\circ} \mathrm{C}$ reduces the flow stress by about $15 \%-20 \%$, approximately. It is likely that further increasing temperature will cause an additional thermal softening effect. However, testing in such conditions is not easy, since the $\gamma$ TiAl will most probably have a high yield strength even in such conditions, which poses some problems in selecting the compression bars material.

The fracture behaviour of the gamma $\mathrm{TiAl}$ in the temperature range studied suggests that ductility in compression does not increase with increasing temperature. In tests performed at $700^{\circ} \mathrm{C}$ and $800^{\circ} \mathrm{C}$ cracking and fracture takes place for macroscopic plastic strain values of 0.32 , approximately. Nevertheless, at room temperature and at $400^{\circ} \mathrm{C}$ such strain values can be exceeded without material macrocracking or fracture. In a next stage, the damage mechanisms developed in the gamma titanium aluminides during hot dynamic compression will be studied, in order to assess the possibility of employing this material in real hot plastic forming processes. 


\section{CONCLUSIONS.}

In this work the dynamic compressional behaviour of gamma titanium aluminides has been studied using the Split Hopkinson Pressure Bar. Room temperature tests were made at strain rates ranging from $161 \mathrm{~s}^{-1}$ to $3960 \mathrm{~s}^{-1}$. Hot dynamic compression tests were made at a strain rate of about $2400 \mathrm{~s}^{-1}$. The microscopic observation of the specimens suggests that the main damage mechanism is crack formation by void nucleation, growth and coalescence along gamma phase lamellae in the $\gamma+\alpha_{2}$ grains. In fact, examination of the fracture surfaces of the specimens tested at $800^{\circ} \mathrm{C}$ shows important crack formation. The intermetallic alloy studied shows a remarkable strain hardening capability at all the testing temperatures.

\section{REFERENCES.}

1. Kim, Y. W., "Gamma Titanium Aluminides: Their Status and Future", J. Metals, 41, 24-30 (1989).

2. Kim, Y.W., in High Temperature Ordered Intermetallic Alloys IV (Eds.: Stiegler, J.O., Johnson, L.A. and Pope, D.P.), pp. 777-794, Pittsburgh, Pennsylvania (1991).

3. Huang, S. C. and Shih, D.S., Microstructure/Property Relationships in Titanium Aluminides and Alloys (Eds.: Kim, Y.W. and Boyer, R.R.), pp. 105-122, Warrendale, Pennsylvania (1990).

4. Tsuyama, S., Mitao, S. and Minakawa, K., Microstructure/Property Relationships in Titanium Aluminides and Alloys, (eds.: Kim, Y.W. and Boyer, R.R.), pp. 297-312, Warrendale, Pennsylvania (1990).

5. Kim, Y.W. and Dimiduk, D.M., "Progress in the Understanding of Gamma Titanium Aluminides", J. Metals, 43, 40-47 (1991).

6. Nicholas, T, "High Strain Rate Characterisation of Materials", in Impact Dynamics (Eds.: Zukas, J.A., Nicholas, T., Suwft, H., Greszczuk and Curran, D.R.), John Wiley \& Sons (1982).

7. Johnson, G.R. and Cook, W.H., "A Constitutive Model And Data For Metals Subjected To Various Strains, Strain Rates, Temperatures And Pressures. " Eng.Fract.Mech, 21, 31-48 (1985).

8. Johnson, G.R. and Cook, W.H., "A Constitutive Model And Data For Metals Subjected To Large Strains, High Strain Rates and High Temperatures. " Proc.7th.Int.Symp.Ballistics, 541-547 (1983)

Acknowledgements. The authors are indebted to the Comisión Interministerial de Ciencia y Tecnologia, through Project MAT96-0649, for the financial support of this work. 